\title{
Influenza A Virus-Infected Lung Epithelial Cell Co-Culture with Human Peripheral Blood Mononuclear Cells
}

\author{
Liyen Loh, Marios Koutsakos, Katherine Kedzierska, \\ and Timothy S. C. Hinks
}

\begin{abstract}
Sensing of influenza A virus (IAV) infection by pattern recognition receptors can occur by either direct infection of lung epithelial cells or uptake of virus-infected cells by innate cells such as dendritic cells/ monocytes. This triggers a series of downstream events including activation of the inflammasome, the production of cytokines, chemokines, and the upregulation of stress-induced ligands that can lead to the activation of innate cells. These cells include innate lymphocytes such as MAIT, NKT, NK, and $\gamma \delta$ T cells. Here we describe a method used to allow activation of human innate lymphocytes in co-culture with an IAV-infected human lung epithelial cell line (A549) to measure ex vivo effector functions (TNF and IFN $\gamma$ ) in a mixed culture environment. We describe (1) infection of the human lung epithelial cell line, (2) co-culture with PBMC, and (3) measurement of activation using intracellular cytokine staining.
\end{abstract}

Key words Virus, MAIT cell, Flow cytometry, Tetramer, Infection, Human, Epithelial cell

1 Introduction

The innate immune response serves as the first line of defense during viral infections. Sensing of influenza A virus (IAV) infection by pattern recognition receptors (e.g., TLR and RIG-I) can occur by either direct infection of lung epithelial cells or uptake of virusinfected cells by innate cells such as dendritic cells/monocytes. This triggers a series of downstream events including activation of the inflammasome, the production of cytokines, chemokines, and the upregulation of stress-induced ligands that can lead to the activation of innate cells. These cells include innate lymphocytes such as MAIT, NKT, NK, and $\gamma \delta$ T cells. These lymphocytes can be activated by non-classical MHC interactions, cytokine-mediated signals or both. This method allows for the activation of human innate lymphocytes in co-culture with IAV-infected human lung epithelial cells (A549) and is used to measure ex vivo effector functions (TNF and IFN $\gamma$ ) in a mixed culture environment [2]. The objective is to 
measure and recapitulate the events of early IAV infection in vitro, in a co-culture system with human peripheral blood mononuclear cells (PBMC) and IAV-infected human lung epithelial cells.

The method described in this chapter comprises three main steps: (1) infection of a human epithelial cell line, (2) co-culture with PBMC to activate the virus responsive cells, and (3) intracellular cytokine staining to measure the extent of functional activation.

\section{Materials}

\subsection{Reagents and Buffers}

1. Complete RPMI (cRPMI): Roswell Park Memorial Media, $10 \%$ heat-inactivated fetal calf serum (FCS), $100 \mathrm{U} / \mathrm{mL}$ Penicillin, $100 \mathrm{U} / \mathrm{mL}$ Streptomycin, and $100 \mu \mathrm{M}$ MEM Vitamins.

2. Human lung epithelial cell line, A549 (ATCC, VA, USA).

3. PR8 virus (influenza A strain/H1Nl/Puerto Rico/1934).

4. Trypsin Versene (In-house preparation).

5. Trypan Blue and Counting Chamber.

6. Brefeldin A-Golgi PLUG (BD, CA, USA).

7. Live/dead Fixable Aqua Dead Cell Stain Kit (ThermoFisher, MA, USA).

8. Cytofix/Cytoperm Fixation/Permeabilization Kit (BD Biosciences, USA).

9. 10\% Lysol or 1\% Virkon.

10. Fluorescence activated flow cytometry (FACS) buffer: phosphate-buffered saline (PBS), $2 \mathrm{mM}$ EDTA, 0.5\% bovine serum albumin (BSA). From a $500 \mathrm{~mL}$ bottle of PBS, add $40 \mathrm{~mL}$ to a $50 \mathrm{~mL}$ falcon containing $2.5 \mathrm{~g}$ BSA powder, vortex hard, then filter-sterilize back into PBS bottle using a syringe through a 0.22 um filter.

11. 1\% paraformaldehyde (PFA) solution. Dilute 16\% paraformaldehyde 1:16 with FACs buffer.

12. Antibodies for flow cytometry (Table 1).

13. Phosphate-buffered saline (PBS).

1. T75 flasks (Corning, NY, USA).

2. $50 \mathrm{~mL}$ Flacon tube (Fischer Scientific, MA, USA).

3. 96-well U-bottom plate polystyrene (Greiner, Germany).

\subsection{Equipment}

1. Flow Cytometer, BD LSR FORTESSA, or equivalent.

2. Water Bath. 
Table 1

Example flow cytometric activation panel and IAV nucleoprotein expression

\begin{tabular}{|c|c|c|c|c|}
\hline Marker & Fluorophore & Laser & Clone & Dilution \\
\hline \multicolumn{5}{|c|}{ Surface stain activation } \\
\hline Live Dead & Aqua & Violet & & $\begin{array}{l}1 / 800 \text { (stain in PBS prior to surface } \\
\text { stain) }\end{array}$ \\
\hline $\begin{array}{l}\text { MRl-5-OP-RU } \\
\text { Tet }\end{array}$ & SA-BV421 & Violet & & $*$ Titrate $1 / 200-1 / 400$ \\
\hline CD19 & APC-H7 & Red & HIB19 & $1 / 100$ \\
\hline $\mathrm{CD} 14$ & APC-H7 & Red & МфР9 & $1 / 100$ \\
\hline $\operatorname{CD} 8 \alpha$ & $\begin{array}{l}\text { PerCP- } \\
\text { Cy5.5 }\end{array}$ & Blue & SKl & $1 / 50$ \\
\hline TCR $\gamma \delta$ & FITC & Blue & $2 \mathrm{Fll}$ & $1 / 50$ \\
\hline CD4 & BV650 & Violet & OKT4 & $1 / 200$ \\
\hline CDl61 & BV605 & Violet & HP-3G10 & $1 / 50$ \\
\hline CD3 & PE-CF594 & $\begin{array}{l}\text { Yellow/ } \\
\text { Green }\end{array}$ & UCHT1 & $1 / 200$ \\
\hline TCR V $\alpha 7.2$ & $\mathrm{PE}$ & $\begin{array}{l}\text { Yellow/ } \\
\text { Green }\end{array}$ & $3 \mathrm{Cl} 10$ & $1 / 200$ \\
\hline CD56 & PE-Cy7 & $\begin{array}{l}\text { Yellow/ } \\
\text { Green }\end{array}$ & NCAMI 6.2 & $1 / 100$ \\
\hline \multicolumn{5}{|c|}{ Intracellular stain activation } \\
\hline TNF & APC & Red & MAbll & $1 / 50$ \\
\hline IFN $\gamma$ & AF700 & Red & $\mathrm{B} 27$ & $1 / 150$ \\
\hline \multicolumn{5}{|c|}{ Intracellular stain IAV-NP infection } \\
\hline IAV nucleoprotein & FITC & Blue & 1331 & $1 / 100$ \\
\hline
\end{tabular}

Typical flow cytometry panel compatible with a four-laser BD LSRII Fortessa flow cytometer, allowing identification of innate and adaptive lymphocyte subsets and assessment of activation measured by intracellular cytokine staining

*Batches of SA-conjugated and Tetramerized MRI-5-OP-RU will vary and require titration prior to usage

\section{Methods}

\subsection{IAV Infection of Human Lung Epithelial Cell Line, A549}

Personal protective equipment (PPE) should be worn at all times (gloves, lab coat, and eye protection) (see Note $\mathbf{l}$ ).

1. 24 h prior to infection, in two T75 flasks, seed $5 \times 10^{6}$ A549 cells in a total volume of $20 \mathrm{~mL}$ of media (one flask for IAV infection and the second flask for uninfected control A549s).

2. On the day of infection: leave one flask of A549 cells in the incubator (uninfected control). Wash the other flask with room 
3.2 Co-Culture (Start During the $1 \mathrm{~h}$ Incubation with Virus) temperature PBS once, cap and gently rotate flask from side to side. Aspirate PBS with glass tissue culture pipette.

3. Thaw virus (PR8) [1] on ice and add $174 \mu \mathrm{L}$ to $10 \mathrm{~mL}$ of room temperature PBS in a $50 \mathrm{~mL}$ falcon tube (depending on viral titer of stock) to achieve a multiplicity of infection (MOI) of $\sim 10-30 *$. Gently pipette this into the T75 containing A549 cells.

* Example calculation of MOl 10:

An MOI of 10 using $1 \times 10^{6}$ PBMC per well requires $1 \times 10^{7}$ virus particles/well. The volume required/well of a $1 \times 10^{9}$ plaque forming units $(\mathrm{pfu}) / \mathrm{mL}$ virus titer is $1 \times 10^{7} \mathrm{pfu} / 1 \times 10^{9} \mathrm{pfu} / \mathrm{mL}=0.01 \mathrm{~mL} /$ well or $10 \mu \mathrm{L} /$ well.

4. Incubate flask horizontally for $1 \mathrm{~h}$ in the $37{ }^{\circ} \mathrm{C}$ incubator $(5 \%$ $\left.\mathrm{CO}_{2}\right)$.

5. Remove both T75 flasks from incubator and add $10 \mathrm{~mL}$ of cRPMI to the flask containing virus. Cap and gently rotate from side to side. Aspirate media from both flasks.

6. To detach A549 cells, wash flasks once with room temperature PBS, aspirate, and add $2.5 \mathrm{~mL}$ of Trypsin versene to each flask. Gently tilt the flask to ensure that the solution coats the entire flask.

7. Incubate for $5 \mathrm{~min}$ in the $37{ }^{\circ} \mathrm{C}$ incubator $\left(5 \% \mathrm{CO}_{2}\right)$.

8. Add $10 \mathrm{~mL}$ of cRPMI to T75 flasks and transfer the contents into two $50 \mathrm{~mL}$ falcon tubes. Centrifuge for $5 \mathrm{~min}$ at $500 \times \mathfrak{g}$, $25^{\circ} \mathrm{C}$. Aspirate supernatant.

9. Resuspend cells in $2 \mathrm{~mL}$ of cRPMI and perform cell counts using trypan blue estimation.

10. Adjust the volume of A549 cells so that the final concentration is $2 \times 10^{6}$ cells $/ \mathrm{mL}$.

1. Thaw PBMCs in $37^{\circ} \mathrm{C}$ water bath and gently pipette dropwise into $9 \mathrm{~mL}$ of pre-warmed cRPMI per cryovial and centrifuge at $500 \times g$ for $5 \mathrm{~min}($ see Note 2 ).

2. Aspirate media and count cells. Resuspend PBMCs at $10 \times 10^{6}$ cells $/ \mathrm{mL}$ in cRPMI. For each sample aliquot $100 \mu \mathrm{L}$ of cells $\left(1 \times 10^{6}\right.$ PBMC) into three wells of a 96-well U-bottom plate. These wells will correspond to Media Control, uninfected A549 + PBMC, and IAV-infected A549 + PBMC, respectively.

To check IAV nucleoprotein levels, see Note 3. Add $100 \mu \mathrm{L}$ of infected and uninfected A549 cells to separate wells in the 96-well plate.

3. Add $100 \mu \mathrm{L}$ of uninfected A549s or IAV-infected A549s $\left(2 \times 10^{5}\right.$ cells $)$ into wells containing PBMC. Leave one well 
with PBMC only, add $100 \mathrm{uL}$ of cRPMI to this well. Place this plate in the $37{ }^{\circ} \mathrm{C}$ incubator $\left(5 \% \mathrm{CO}_{2}\right)$.

4. After 3-4 h, add brefeldin A (BFA-GOLGI PLUG), 1:2000 to all wells and incubate for a further $6 \mathrm{~h}$ in the $37^{\circ} \mathrm{C}$ incubator (total co-culture $10 \mathrm{~h}$ ).

5. Remove plate and continue with intracellular cytokine (ICS) staining or place in the $4{ }^{\circ} \mathrm{C}$ covered in foil to stain the next day.

\subsection{Intracellular Cytokine Staining}

1. Spin down plate by centrifuging at $400 \times g$ for $5 \mathrm{~min}$ at $4{ }^{\circ} \mathrm{C}$. Discard supernatant in waste container containing 10\% Lysol or $1 \%$ Virkon in class II biosafety cabinet.

2. Stain cells with live/dead discrimination marker Aqua (1:800) final volume of $50 \mu \mathrm{L} /$ well. Use PBS as a diluent (see Note 4). Incubate at room temperature in the dark for $15 \mathrm{~min}$.

3. Centrifuge plate at $400 \times g$ for $5 \mathrm{~min}$ at $4{ }^{\circ} \mathrm{C}$. Discard supernatant.

4. Add $50 \mu \mathrm{L}$ of surface phenotype stain (Table 1 ) to each well. Incubate for $30 \mathrm{~min}$ on ice, in the dark.

5. Wash cells once with $150 \mu \mathrm{L}$ of FACs buffer. Centrifuge for $5 \mathrm{~min}$ at $1500 \mathrm{rpm}, 4^{\circ} \mathrm{C}$. Flick off supernatant in discard container in biohazard cabinet.

6. Resuspend the cells in $100 \mu \mathrm{L}$ of cold cytofix/perm solution and incubate on ice in the dark for $20 \mathrm{~min}$.

7. Wash cells with $100 \mu \mathrm{L}$ of diluted $\left(1: 10\right.$ in $\left.\mathrm{dH}_{2} \mathrm{O}\right)$ perm/wash buffer. Centrifuge for $5 \mathrm{~min}$ at $450 \times \mathfrak{g}, 4^{\circ} \mathrm{C}$.

8. Resuspend cells in $50 \mu \mathrm{L}$ of intracellular cytokine stain, see (Table 1) below. Incubate on ice in the dark for $30 \mathrm{~min}$.

9. Wash cells with $150 \mu \mathrm{L}$ of perm/wash buffer. Centrifuge for $5 \mathrm{~min}$ at $450 \times \mathfrak{g}, 4^{\circ} \mathrm{C}$.

10. Repeat with a second wash with $200 \mu \mathrm{L}$ of FACs buffer. Centrifuge for $5 \mathrm{~min}$ at $450 \times \mathfrak{g}, 4^{\circ} \mathrm{C}$.

11. Resuspend cells in $100 \mu \mathrm{L}$ of $1 \%$ PFA and transfer to bullet tubes. Keep samples in the dark and at cold until acquisition on the flow cytometer. For suggested flow cytometric gating strategy see Fig. 1.

\section{Notes}

1. Biological Hazards-Human PBMC samples are classified as non-infectious. Influenza A virus-PR8-strain $(\mathrm{HlNl})$ is a lab-adapted strain of IAV virus. Work should be risk assessed, and we recommend controls which include but are not restricted to the following: Lab coat, safety glasses, and gloves 


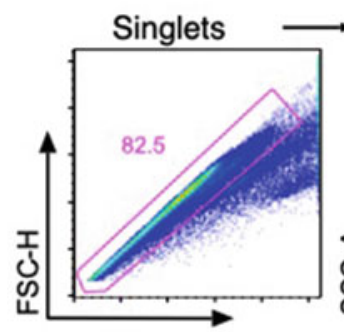

FSC-A
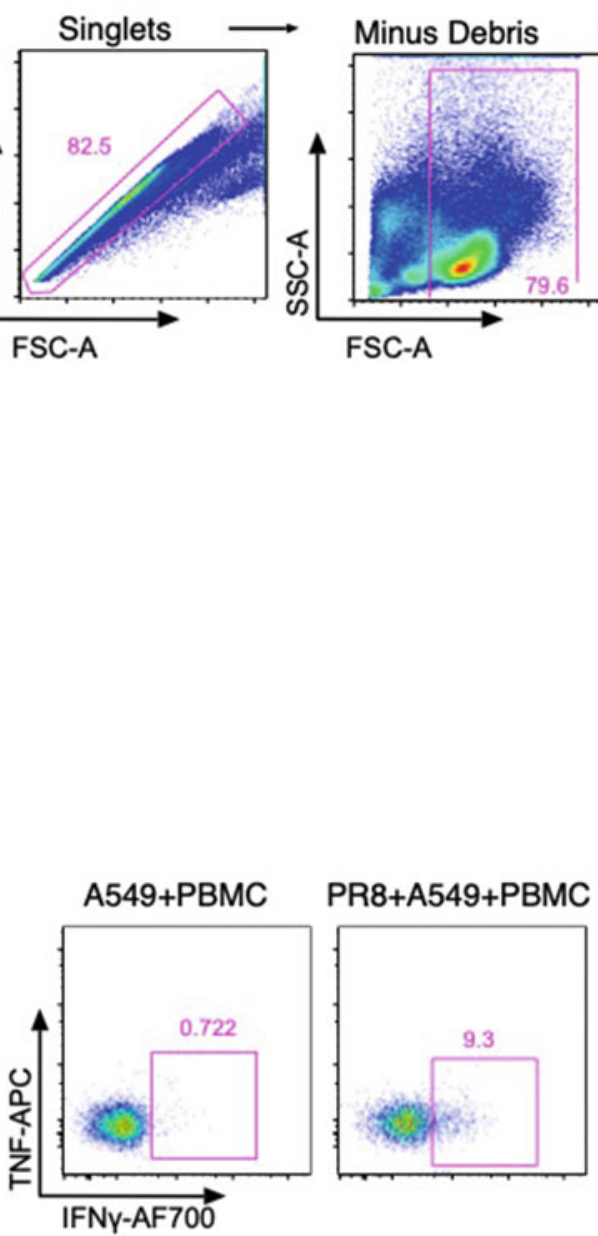

PR8+A549+PBMC

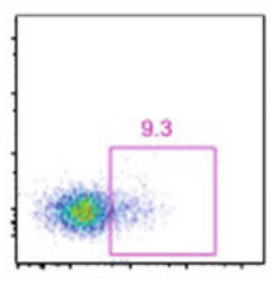

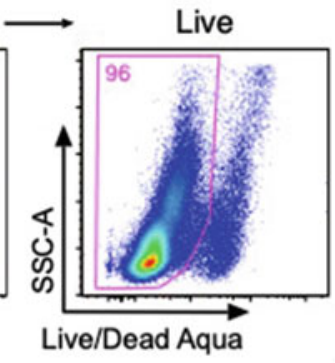
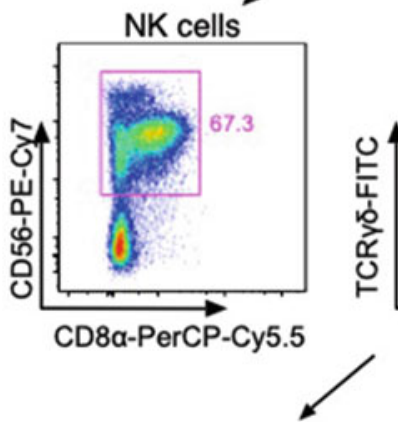

MR1-5-OP-RU+Va7.2 ${ }^{+}$

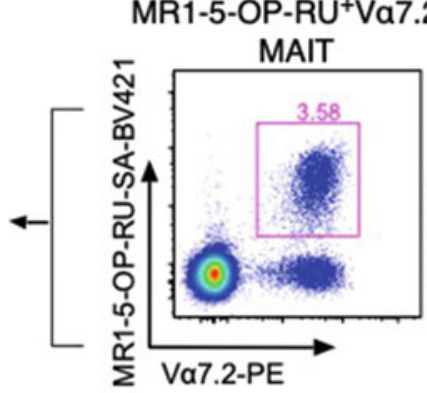

CD14/19 Dump Gate

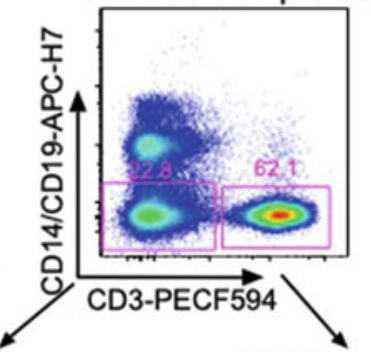

T cells

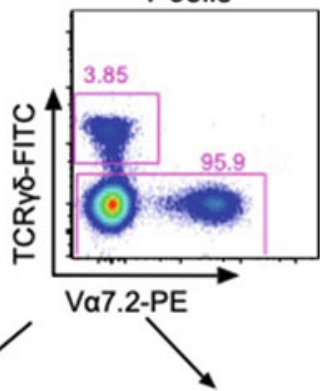

$\mathrm{CD} 161^{+} \mathrm{Va} 7.2^{+}$
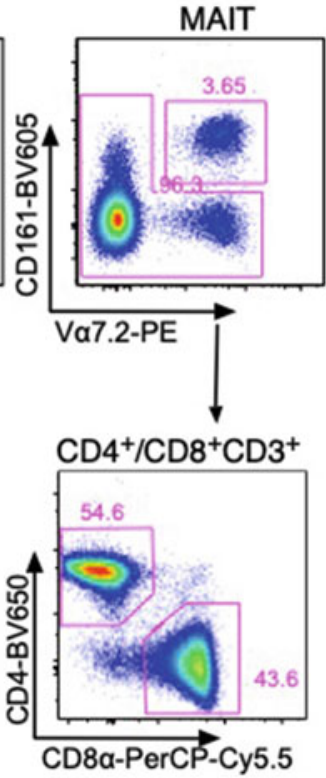

Fig. 1 Flow cytometry gating strategy for MAIT cells and other lymphocyte subsets

should be worn when performing this protocol. Work with human PBMCs and virus in a Class II biohazard cabinet. Use filter tips when working with virus. Decontaminate all pipette tips that have been used for human and virus work in $10 \%$ lysol or $1 \%$ Virkon when working in the biohazard cabinet. After use, the biohazard hood should be decontaminated by wiping down with $70 \%$ ethanol and by UV sterilization for $15 \mathrm{~min}$ 
before any further use. All waste and its container must be disposed as hazardous waste.

2. MAIT cell responses after in vitro influenza co-culture are highly variable between donors. Freshly processed PBMCs may aid in the detection of IFN $\gamma$ cytokine responses after influenza co-culture.

3. To determine if influenza virus infection of lung epithelial cells is successful after $10 \mathrm{~h}$ of culture, intracellular cytokine staining for influenza A virus nucleoprotein is determined by flow cytometry. Follow steps $\mathbf{1 - 3}$ and $\mathbf{6 - 1 1}$ of Subheading 3.3 Intracellular cytokine staining.

4. Fixable viability dyes react with exposed amine groups within permeable cells. Therefore, to prevent wasteful reaction with proteins in cytometry buffers, it is recommended to resuspend cells in protein-free media for the viability staining step.

\section{Acknowledgments}

This work was funded by grants to TSCH from the Wellcome Trust (104553/z/14/z, $211050 / Z / 18 / z)$ and K.K from the National Health and Medical Research Council (NHMRC) Program Grant (1071916). K.K. is an NHMRC Senior Research Fellow (1102792). The content represents only the authors' views and not those of the European Commission.

\section{References}

1. Koutsakos M, Illing PT, Nguyen THO et al (2019) Human CD8(+) T cell cross-reactivity across influenza $\mathrm{A}, \mathrm{B}$ and $\mathrm{C}$ viruses. Nat Immunol
2. Loh L, Wang Z, Sant S et al (2016) Human mucosal-associated invariant $\mathrm{T}$ cells contribute to antiviral influenza immunity via IL-18-dependent activation. Proc Natl Acad Sci U S A 113:10,133-10,138

Open Access This chapter is licensed under the terms of the Creative Commons Attribution 4.0 International License (http://creativecommons.org/licenses/by/4.0/), which permits use, sharing, adaptation, distribution and reproduction in any medium or format, as long as you give appropriate credit to the original author(s) and the source, provide a link to the Creative Commons license and indicate if changes were made.

The images or other third party material in this chapter are included in the chapter's Creative Commons license, unless indicated otherwise in a credit line to the material. If material is not included in the chapter's Creative Commons license and your intended use is not permitted by statutory regulation or exceeds the permitted use, you will need to obtain permission directly from the copyright holder. 